\title{
Biochemical Characteristics and Fatty Acid Compositions of Some Armadillo-derived Mycobacteria and Their Relation to Mycobacterium gordonae
}

\author{
By F. PORTAELS,${ }^{1 *}$ L. LARSSON $^{2}$ J. JIMENEZ ${ }^{2}$ AND C. CIERKENS ${ }^{1}$ \\ ${ }^{1}$ Department of Microbiology, Institute of Tropical Medicine, Nationalestraat 155, \\ Antwerp B 2018, Belgium \\ ${ }^{2}$ Department of Medical Microbiology, University of Lund, Lund, Sweden
}

(Received 3 September 1986; revised 27 October 1986)

\begin{abstract}
The long-chain components of 75 strains of mycobacteria, cultivated from Mycobacterium leprae-infected or non-infected armadillos, and of eight clinical and 15 environmental isolates of $M$. gordonae, were compared. Four major groups could be distinguished based on the presence of 10-methyloctadecanoic (tuberculostearic) and 2-methyl 3-hydroxyeicosanoic acids and secondary alcohols (2-octadecanol and 2-eicosanol). Some heterogeneity was found in strains assigned to $M$. gordonae : the characteristic absence of tuberculostearic acid and secondary alcohols and the presence of the branched C14 and the hydroxylated C20 acids were seen in only 34 of the 49 strains studied. Three strains were identified as $M$. malmoense, one as $M$. kansasii, ten as belonging to the $M$. avium-M. intracellulare-M. scrofulaceum complex and eight as belonging to new groups of armadillo-derived mycobacteria (ADM 1, ADM 2 and ADM 3) by conventional bacteriological tests and fatty acid compositions, though $M$. malmoense was heterogeneous in its fatty acids composition. Four strains, identified as $M$. avium by conventional tests, differed from this species by their fatty acid compositions. Thirteen strains showed some similarity to $M$. simiae and ten strains differed from all other known mycobacteria.
\end{abstract}

\section{INTRODUCTION}

The isolation of several strains of Mycobacterium from wild armadillos (F. Portaels \& G. P. Walsh, unpublished results) and armadillos experimentally infected with Mycobacterium leprae (Portaels et al., 1982, 1985) was recently reported. The majority of the strains have been identified as belonging to the Mycobacterium avium-intracellulare-scrofulaceum (MAIS) complex or as Mycobacterium gordonae (Portaels et al., 1985). In addition, unclassified armadillo-derived mycobacteria (ADM) have been found. In a comprehensive study involving several laboratories, five groups of ADM could be distinguished, each different from all other mycobacterial species presently recognized (Portaels et al., 1986).

The potential of fatty acid analysis in systematic studies of mycobacteria has been pointed out by several authors (Minnikin \& Goodfellow, 1980; Daffé et al., 1983; Minnikin et al., 1984; Dobson et al., 1985; Larsson et al., 1985a). The objective of the present study was to evaluate the fatty and mycolic acid compositions of several ADM using gas chromatographic (GC) and thinlayer chromatographic (TLC) analyses. For comparison, clinical and environmental isolates of $M$. gordonae were also studied.

\section{METHODS}

Mycobacteria. Ninety-eight strains were analysed (Table 1), 75 of which had been isolated from 45 tissues (livers, spleens, lymph nodes) of 35 different armadillos (Portaels et al., 1985). Fifteen strains of $M$. gordonae were isolated from the soil in Zaire and Florida (Portaels, 1978), and eight $M$. gordonae strains were human isolates

\footnotetext{
Abbreviations: MAIS, $M$. avium-intracellulare-scrofulaceum complex; ADM, armadillo-derived mycobacteria.
} 


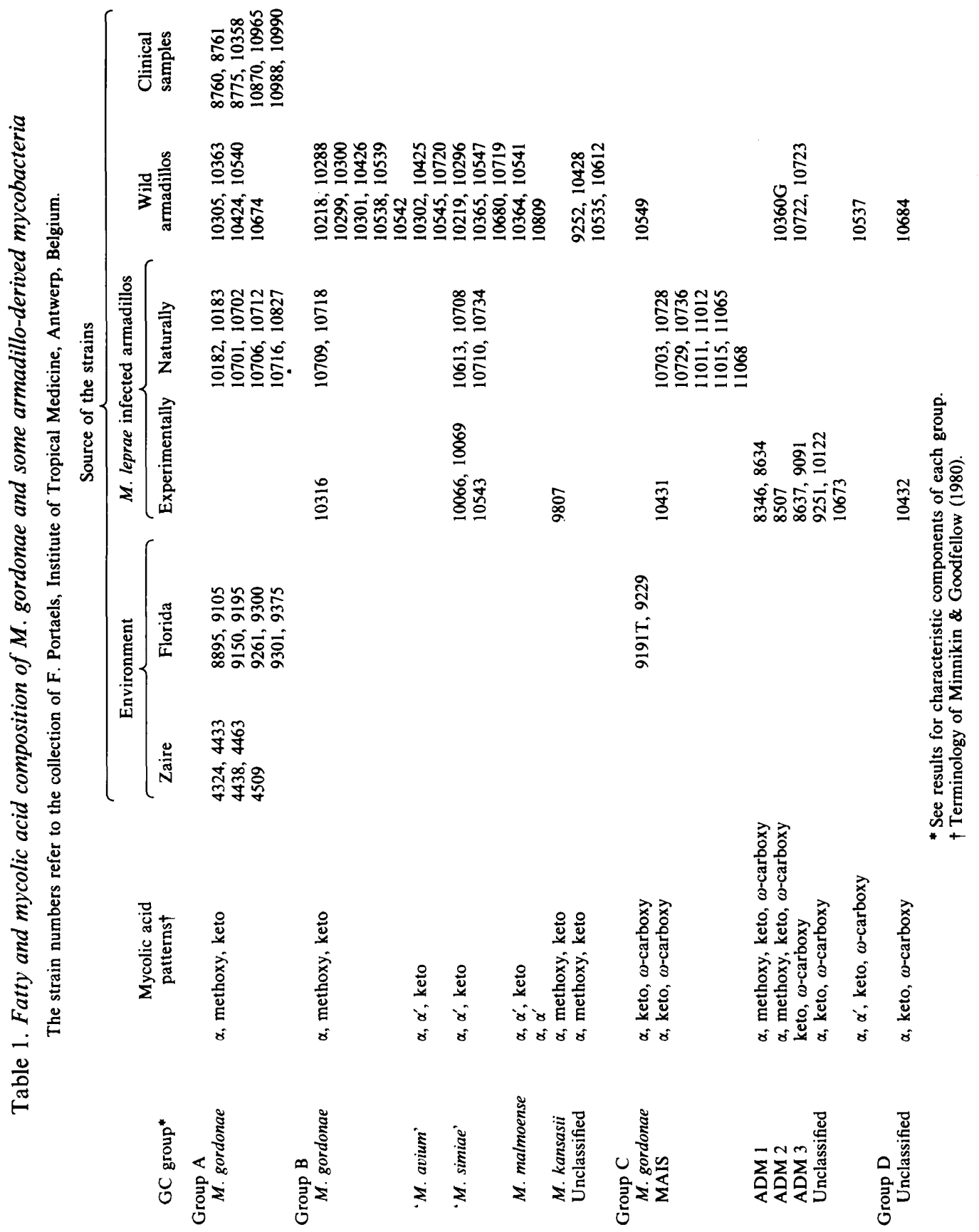


recovered from sputum specimens and skin biopsies (Petroff, 1915). The strains were identified as described by Jenkins et al. (1982).

The mycobacteria were cultivated on Löwenstein-Jensen or Ogawa egg yolk medium without malachite green (Portaels et al., 1985). Cells were collected after $1-6$ weeks incubation at $37^{\circ} \mathrm{C}$, killed with formalin $(1 \%$, v/v) and freeze-dried before being subjected to TLC and GC analysis.

$T L C$. Mycolic acid methyl esters, obtained after heating the cells in an alkaline methanolic solution followed by esterification of the acids using iodomethane (Dobson et al., 1985), were analysed by two-dimensional TLC (Minnikin et al., 1984; Dobson et al., 1985).

$G C$. Freeze-dried cells were heated overnight in methanolic $\mathrm{HCl}$ after which the fatty acid methyl esters and long-chain alcohols were extracted (Larsson, 1983). Trifluoroacetylation was used for identification of hydroxylated esters and alcohols. The extracts were introduced and separated on a narrow-bore fused silica capillary column using splitless injection (Larsson \& Odham, 1984) as previously reported (Larsson et al., 1985 b).

\section{RESULTS}

Of the heterogeneous GC profiles obtained, four major groups (A, B, C and D) of mycobacteria could be distinguished based on the presence of 2-methyltetradecanoic, 10methyloctadecanoic (tuberculostearic) and 2-methyl 3-hydroxyeicosanoic acids, and secondary alcohols (2-octadecanol and 2-eicosanol). Variations in incubation time and culture medium did not affect these components significantly. A number of compounds eluting after tuberculostearate were occasionally detected; however, most of them were found to originate from small amounts of the culture medium itself present as a contaminant. The results are summarized in Table 1 .

Thirty-four strains ( 13 from armadillos, 13 from the soil and all the eight clinical isolates) were classified as belonging to group A. They were characterized by the presence of the branchedchain $\mathrm{C} 14$ and the hydroxylated $\mathrm{C} 20$ acid, and the absence (or presence in trace amounts) of tuberculostearic acid and secondary alcohols. These strains were very homogeneous, not only according to the GC profiles but also the mycolate patterns; they all contained $\alpha-$, methoxy- and ketomycolates. These strains were identified as $M$. gordonae.

Thirty-seven strains, all isolated from armadillos, belonged to group B. Tuberculostearate, but neither the branched-chain C14 nor the hydroxylated C20 acid, nor any of the secondary alcohols, was detected. Twelve strains produced the typical $M$. gordonae mycolate pattern and were identified as $M$. gordonae by conventional tests. Four strains produced $\alpha-, \alpha^{\prime}-$ and ketomycolates, just as $M$. simiae, but they had the cultural, physiological and biochemical properties of $M$. avium. Thirteen additional strains contained the same mycolates as $M$. simiae but differed from $M$. simiae in that they were non-chromogenic, did not produce niacin and gave less than $45 \mathrm{~mm}$ foam in the semi-quantitative catalase test (Table 2). Three strains were identified as $M$. malmoense: Tween 80 was hydrolysed after $1 \mathrm{~d}$, the strains had low catalase activity (less than $45 \mathrm{~mm}$ foam) and were sensitive to isoniazid $\left(10 \mu \mathrm{g} \mathrm{ml}^{-1}\right)$. One of these strains (10541) was subjected to TLC analysis of its surface lipids (Jenkins, 1980); the unique pattern of spots characteristic for M. malmoense was found (P. A. Jenkins, personal communication). The mycolate pattern of two of the strains was identical to that of $M$. simiae $\left(\alpha-, \alpha^{\prime}-\right.$ and ketomycolates) while one strain (10809) contained $\alpha$-and $\alpha^{\prime}$-mycolates, just as $M$. chelonae (Daffé et al., 1983; Minnikin et al., 1984). The three M. malmoense strains differed also with respect to their GC patterns: two of them contained an unidentified fatty acid eluting just after $C 20: 0$, whereas in the remaining strain (10809) this acid was absent. One strain (9807), which contained 2,4-dimethyl tetradecanoic acid, was identified as $M$. kansasii. Its mycolate pattern was similar to that of $M$. gordonae. Four strains with similar mycolate compositions ( $\alpha$-, methoxy- and ketomycolates) formed a heterogeneous group according to their cultural, physiological and biochemical properties, and were not considered as belonging to any of the presently recognized mycobacterial species.

Tuberculostearate and secondary alcohols were found in appreciable amounts in the 25 strains (including three $M$. gordonae strains) in group C. Ten of the strains belonged to the MAIS complex and contained $\alpha$, keto- and $\omega$-carboxymycolates, this being the characteristic pattern for this complex. Eight strains were divided into homogeneous groups: ADM 1, ADM 2 and 
Table 2. Characteristics of $M$. simiae and related strains isolated from armadillos

\begin{abstract}
All the strains tested grew in the presence of thiophene-2-carboxylic acid hydrazide $\left(1 \mu \mathrm{g} \mathrm{ml}^{-1}\right)$ or $p$ nitrobenzoic acid $\left(500 \mu \mathrm{g} \mathrm{ml}^{-1}\right)$, but none grew in the presence of $5 \%(\mathrm{w} / \mathrm{v}) \mathrm{NaCl}$; none of the strains reduced nitrate, produced acid phosphatase or hydrolysed Tween 80 .
\end{abstract}

\begin{tabular}{lcc} 
Character & 90 & $\begin{array}{c}\text { Percentage of strains } \\
\text { Resitive in each test } \\
\text { Wayne } \text { et al. }(1983)\end{array}$ \\
\cline { 2 - 3 } Photochromogenic & $\begin{array}{c}\text { 'M. simiae' from } \\
\text { armadillos }\end{array}$ \\
Pigment produced & 90 & 0 \\
Growth in media containing: & 70 & 0 \\
$\quad$ isoniazid $\left(10 \mu \mathrm{gl}^{-1}\right)$ & 100 & 46 \\
$\quad$ hydroxylamine hydrochloride $\left(250 \mu \mathrm{g} \mathrm{ml}^{-1}\right)$ & 100 & 69 \\
Catalase $(>45 \mathrm{~mm})$ & 100 & 0 \\
Urease & 46 & 92 \\
Niacin accumulated & 11 & 0 \\
$\quad$ No. of strains tested & & 13
\end{tabular}

ADM 3 (Portaels et al., 1986). The ADM 1 and ADM 2 strains contained $\alpha-$, methoxy-, ketoand $\omega$-carboxymycolates, and the ADM 3 strains keto- and $\omega$-carboxymycolates. Four additional group $\mathrm{C}$ strains formed a heterogeneous group of mycobacteria which appeared different from all other known mycobacteria: three strains contained $\alpha$-, keto- and $\omega$ carboxymycolates, and the remaining strain (10537) contained $\alpha-, \alpha^{\prime}-$, keto- and $\omega$ carboxymycolates.

The GC profiles of the two group D strains differed from those of group C by the absence of tuberculostearate. Both group D strains contained $\alpha$-, keto- and $\omega$-carboxymycolates. One strain (10432) was rapid-growing and the other (10684) slow-growing; both were regarded as 'unclassified' because they did not fit into the established taxonomic schemes of Jenkins et al. (1982).

\title{
DISCUSSION
}

The present study shows that mycobacteria with very different properties can be isolated from armadillos. Clearly, care must be taken to avoid the presence of such bacteria in preparations of $M$. leprae intended for purposes such as vaccine production.

Long-chain secondary alcohols (2-octadecanol and 2-eicosanol), which are released along with $\omega$-carboxymycolates from wax ester mycolates by acid or alkaline hydrolysis, are useful chemical markers in mycobacterial differentiation (Minnikin \& Goodfellow, 1980; Daffé et al., 1983; Larsson, 1983; Larsson et al., 1985a, b). However, these alcohols (and the $\omega-$ carboxymycolates), which have so far consistently been detected in strains belonging to the MAIS complex (Larsson, 1983; Daffé et al., 1983; Minnikin et al., 1984), were not found in four of the studied strains tentatively identified by conventional tests as belonging to $M$. avium. Additional studies, such as DNA:DNA homology analysis, are required to confirm their identities; indeed, it has been reported that species which are very similar on the basis of their phenetic characters may show low DNA relatedness among themselves (Portaels et al., 1986).

The heterogeneity found for $M$. gordonae is noteworthy. Absence of tuberculostearic acid and secondary alcohols, and the presence of the branched-chain $\mathrm{C} 14$ and the hydroxylated $\mathrm{C} 20$ acid, are considered as characteristic features for this species (Tisdall et al., 1979; Julack et al., 1980). These characteristics were found for all of the eight clinical $M$. gordonae isolates, 13 of the 26 strains isolated from armadillos and 13 of the 15 environmental strains. However, $15 \mathrm{M}$. gordonae strains (in groups B and C) produced tuberculostearate in appreciable amounts (about $5 \%$ of the total fatty acids) whereas the branched-chain $\mathrm{Cl} 4$ acid was not detected. In addition, three of these strains (belonging to group C) contained the secondary alcohols. None of the $M$. 
gordonae strains isolated from armadillos experimentally infected with $M$. leprae belonged to group A, and none of the environmental and clinical isolates belonged to group B. A more comprehensive study on $M$. gordonae of different origins should be undertaken in order to relate the different fatty acid compositions to results of genome studies such as DNA:DNA homology analysis. More extensive studies are also necessary for clarifying the taxonomic positions of the two strains classified in group D.

It has been reported that some proposed intermediate MAIS strains may in fact be regarded as belonging to $M$. simiae although photochromogenicity is lacking (Wayne et al., 1983). Even though $M$. simiae might be quite variable in its pigment production (Wayne et al., 1981), our ' $M$. simiae' strains all differed from the reference strains by having low catalase activity. Our strains, although isolated from different animals, formed a very homogeneous group of mycobacteria; additional studies are required before it can be suggested that they might constitute a new species.

The $M$. malmoense strains were readily identified by different biochemical tests. The two types of mycolate and fatty acid patterns found may be related to the different lipid patterns reported by Jenkins (1985).

GC analysis of 2-octadecanol and 2-eicosanol is a useful method for detecting certain mycobacterial contaminants in preparations of $M$. leprae (Larsson et al., 1985b). However, the armadillo tissues may also be contaminated with mycobacterial species lacking $\omega$ carboxymycolates. In view of this, 2-methyltetradecanoic and 2-methyl 3-hydroxyeicosanoic acids should prove to be useful compounds for revealing the presence of at least certain strains of $M$. gordonae. It seems important to search for additional chemical markers in order to be able to detect all the various cultivable mycobacteria which may be present as contaminants in $M$. leprae preparations.

This study was supported by the Damien Foundation, Brussels (F. Portaels and C. Cierkens) and the Swedish National Association against Heart and Chest Diseases (L. Larsson). We wish to thank Mrs. Y. Baeten for preparation of the manuscript. We also thank P. A. Jenkins for confirming the identity of one M. malmoense strain by lipid analysis.

\section{REFERENCES}

Daffé, M., Lanéelle, M. A., Asselineau, C., LeVyFrebaulT, V. \& DAVID, H. (1983). Intérêt taxonomique des acides gras des mycobactéries: proposition d'une méthode d'analyse. Annales de microbiologie 134B, 241-256.

Dobson, G., Minnikin, D. E., Minnikin, S. M., Parlett, J. M., Goodfellow, M., Ridell, M. \& Magnusson, M. (1985). Systematic analysis of complex mycobacterial lipids. In Chemical Methods in Bacterial Systematics, pp. 237-265. Edited by M. Goodfellow \& D. E. Minnikin. London: Academic Press.

JENKINS, P. A. (1980). Thin-layer chromatography of mycobacterial lipids as an aid to classification. In Mycobackterien und mycobacterielle Krankheiten, vol. 1, Systematik der Mycobakterien, pp. 308-318. Edited by G. Meissner \& R. Pfaffenberg. Jena: Gustav Fischer.

JENKINS, P. A. (1985). Mycobacterium malmoense. Tubercle 66, 193-195.

Jenkins, P. A., Pattyn, S. R. \& Portaels, F. (1982). Diagnostic bacteriology. In The Biology of the Mycobacteria, pp. 441-471. Edited by C. Ratledge and J. L. Stanford. London: Academic Press.

Julak, J., TureceK, F. \& Mikova, Z. (1980). Identification of characteristic branched-chain fatty acids of Mycobacterium kansasii and gordonae by gas chromatography-mass spectrometry. Journal of Chromatography 190, 183-187.
LARSSON, L. (1983). Acidic methanolysis v. alkaline saponification in gas chromatographic characterization of mycobacteria: differentiation between $\mathrm{Myco-}$ bacterium avium-intracellulare and Mycobacterium gastri. Acta pathologica microbiologica et immunologica scandinavica B91, 235-239.

LARSSON, L. \& ODHAM, G. (1984). Injection principles in capillary gas chromatographic analysis of bacterial fatty acids. Journal of Microbiological Methods 3, 77-82.

LARSSON, L., JANTZEN, E. \& JohnsSON, J. (1985a). Gas chromatographic fatty acid profiles for characterisation of mycobacteria: an interlaboratory methodological evaluation. European Journal of Clinical Microbiology 4, 483-487.

Larsson, L., Draper, P. \& Portaels, F. (1985 b). Use of gas chromatography to differentiate Mycobacterium leprae from cultivable armadillo derived mycobacteria, $M$. avium-intracellulare and $M$. lepraemurium by analysis of secondary alcohols. International Journal of Leprosy 53, 441-446.

MinNikin, D. E. \& Goodfellow, M. (1980). Lipid composition in the classification and identification of acid fast bacteria. In Microbiological Classification and Identification, pp. 189-256. Edited by $M$. Goodfellow \& R. G. Board. London: Academic Press.

Minnikin, D. E., Minnikin, S. M., Parlett, J. M., Goodfellow, M. \& MaGnUsSon, M. (1984). Myco- 
lic acid patterns of some species of Mycobacterium. Archives of Microbiology 139, 225-231.

PETroff, S. A. (1915). A new and rapid method for the isolation and cultivation of tubercle bacilli directly from sputum and feces. Journal of Experimental Medicine 21, 38-42.

PORTAELS, F. (1978). Etude d'Actinomycétales isolées de l'homme et de son environnement en Afrique Centrale. Doctoral thesis, University of Brussels, Belgium.

Portaels, F., Francken, A. \& Pattyn, S. R. (1982). Bacteriological studies of armadillo livers infected with Mycobacterium leprae. Annales de la Société belge de médecine tropicale 62, 233-245.

PORTAELS, F., De Ridder, K. \& PATtYN, S. R. (1985). Cultivable mycobacteria isolated from organs of armadillos uninoculated and inoculated with $\mathrm{Myco}$ bacterium leprae. Annales de microbiologie 136A, 181190.

Portaels, F., Asselineau, C., Baess, I., Daffé, M., Dobson, G., Draper, P., Gregory, D., Hall, R. M., Imaeda, T., Jenkins, P. A., Lanéelle, M. A., Larsson, L., Magnusson, M., MinNikin, D. E., Pattyn, S. R., Wieten, G. \& Wheeler, P. R. (1986). A cooperative taxonomic study of mycobacteria isolated from armadillos infected with $M$. leprae. Journal of General Microbiology 132, 2693 2707.

Tisdall, P. A., Roberts, G. D. \& Anhalt, J. P. (1979). Identification of clinical isolates of mycobac- teria with gas-liquid chromatography alone. Journal of Clinical Microbiology 10, 506-515.

WAYNe, L. G., GoOd, R. C., KRIChevsky, M. I., Blacklock, Z., Chaparas, S. D., Dawson, D., Froman, S., Gross, W., Hawkins, J., JENKINS, P. A., JUhlin, I., KAPPLER, W., KLEEBERG, H. H., Krasnow, I., Lefford, M. J., Mankiewicz, E., McDurmont, C., Meissner, G., Nel, E. E., Pattyn, S. R., Portaels, F., Richards, P. A., Rusch, S., Schroder, K. H., Szabo, I. G., TSUKAMURA, M. \& VERGMANN, B. (1981). First report of the cooperative open ended study of slowly growing mycobacteria by the International Working Group on Mycobacterial Taxonomy. International Journal of Systematic Bacteriology 31, 1-20.

Wayne, L. G., GoOd, R. C., KRIChevSKY, M. I., Beam, R. E., Blacklock, Z., David, H. L., Dawson, D., Gross, W., Hawkins, J., Jenkins, P. A., Juhlin, I., Kappler, W., KleeberG, H. H., Krasnow, I., LefFord, M. J., Mankiewicz, E., McDurmont, C., Nel, E. E., Portaels, F., Richards, P. A., Rusch, S., Schroder, K. H., SilcoX, V. A., Szabo, I., Tsukamura, M., Van deN BreEN, L. \& VergmanN, B. (1983). Second report of the cooperative open ended study of slowly growing mycobacteria by the International Working Group on Mycobacterial Taxonomy. International Journal of Systematic Bacteriology 33, 265-274. 